\title{
Arıotu (Phacelia tanacetifolia Bentham)'nda farklı tohum miktarlarının bitkisel özellikleri ile kalitesi üzerine etkisi
}

\section{The effect of different seed quantities on plant characteristics and quality of phacelia (Phacelia tanacetifolia Bentham)}

\author{
Mustafa OKANT $^{1}$ iD, \\ ${ }^{1}$ Harran Üniversitesi, Ziraat Fakültesi, Tarla Bitkileri Bölümü, ŞANLIURFA/TÜRKIYE
}

To cite this article:

Okant, M. (2018). Arıotu (Phacelia tanacetifolia Bentham)'nda farklı tohum miktarlarının bitkisel özellikleri ile kalitesi üzerine etkisi. Harran Tarım ve Gıda Bilimleri Dergisi, 23(1): 47-51. DOI: 10.29050/harranziraat.423700

Address for Correspondence: Mustafa OKANT

e-mail:

mokant63@yahoo.com

\section{Received Date:}

15.05.2018

Accepted Date:

12.10.2018

( $)$ Copyright 2018 by Harran University Faculty of Agriculture. Available on-line at www.dergipark.gov.tr/harranziraat

This work is licensed under a Creative Commons AttributionNon Commercial

\section{Öz}

Bu araştırma arıotuna uygulanan değişik tohum miktarlarının (1.0, 1.5, 2.0 ve $\left.2.5 \mathrm{~kg} \mathrm{da}^{-1}\right)$ ot verimi ve bazı bitkisel özelliklere etkilerini belirlemek amacıyla, Şanlıurfa ilinde 2016-2017 sezonunda, tesadüf blokları deneme desenine göre 4 tekerrürlü olarak yürütülmüştür. Çalışma sonucunda; Farklı tohum miktarlarında bitki boyu $48.5-60.2 \mathrm{~cm}$, yeşil ot verimi 2191.5-3113.2 $\mathrm{kg} \mathrm{da}^{-1}$, kuru ot verimi 403.4-508.7 $\mathrm{kg} \mathrm{da}^{-1}$ ve ham protein oranı değerleri \%11.5-12.9 arasında değişim gösterdiği saptanmıştır. Araştırmada elde edilen sonuçlara göre, Şanlıurfa ili iklim ve toprak koşullarında kaliteli ve yüksek ot üretimi için $1.5 \mathrm{~kg} \mathrm{da}{ }^{-1}$ tohum kullanımının bölgeye uygun olabileceği saptanmıştır.

Anahtar Kelimeler: Arıotu, Tohum miktarı, Yeşil ve kuru ot verimi, Protein oranı

\section{ABSTRACT}

This research was carried out to determine the effects of different seed quantities $(1.0,1.5$, 2.0 and $2.5 \mathrm{~kg} \mathrm{da}^{-1}$ ) on some plant characters and quality characteristics on phacelia, in the province of Şanlıurfa, Turkey in 2016-2017 growing season. The experiment was in randomized complete block design with 4 replications. According to the study results, plant height ranged from 48.5 to $60.2 \mathrm{~cm}$, green herbage yield $2191.5-3113.2 \mathrm{~kg} \mathrm{da}^{-1}$, dry herbage yield 403.4-508.7 $\mathrm{kg} \mathrm{da}^{-1}$ and crude protein $11.5-12.9 \%$ were determined. Based on the results obtained in the research, it was determined that the use of $1.5 \mathrm{~kg} \mathrm{da}^{-1}$ seeding could be suitable to obtain high yield and good quality in the climate and soil conditions of Şanlıurfa province.

Key Words: Phacelia, Amount of seed, Green and dry herbage yield, Protein ratio

\section{Giriş}

Hayvansal üretimin yetersiz kaldığı ülkemizde bu sorunun temelini kaba yem üretimindeki sorunlar oluşturmaktadır. Kaba yem kaynağını çayır meralar ve tarla tarımı içerisinde yem bitkileri yetiştiriciliği oluşturmaktadır. Meralarımızın üzerindeki yoğun otlatma baskısı ve ıslah projelerinin yaygın olarak uygulanamaması meralardan beklenen verimin elde edilememesi ile sonuçlanmaktadır. Kısa vadede meralardan mevcut potansiyellerinin üstünde bir verim üretimi sağlanamayacağından kaba yem ihtiyacının karşılanmasında en kestirme yol yem bitkileri tarımının artırımasıdır. Yem bitkileri üretimi, kaba yem açığının kapanmasına katkı sağlamakla birlikte, toprağın fiziksel, kimyasal ve biyolojik özelliklerini de iyileştirerek, sürdürülebilir tarıma imkan sağlamaktadır (Tuncer, 2014).

Yem bitkileri üretimi daha çok hayvancılık yapan işletmelerde kendi kaba yem ihtiyacını 
karşılamak amacı ile yapılmaktadır. Bu durum yem bitkileri üretim alanlarını kısıtlayıcı bir etken olmaktadır. Yem bitkileri yetiştiriciliğinde yonca, fiğ gibi daha yaygın olarak bilinen türler tercih edilmektedir. Yem bitkileri üretim alanlarının artırılması için, bölge ekolojilerine uygun olabilecek, alternatif yem bitkilerinin mevcut potansiyellerinin de ortaya konulması gerekmektedir. Sabancı ve ark. (2010), yem bitkileri üretiminin artırılması için alternatif yem bitkilerinin de ürün desenine alınmasını önermektedir.

Arıotu, farklı kullanım olanaklarına sahip bir bitkidir. Çoğunlukla arı merası olarak kullanılmakla birlikte yem bitkisi olarak da kullanılabildiği araştırıcılar tarafından ortaya konulmuştur (Karadağ ve Büyükburç, 2001; Ateş ve ark., 2010; Genç Lermi ve Palta, 2014).

Kuzey Amerika orijinli, tek yıllık, uzun gün bitkisi olan arıotu, Hydrophillaceae familyasından Phacelia cinsine ait (Phacelia tanacetifolia) (Jepson, 1970; Munz, 1973), Ilıman iklime sahip bölgelerde, kışlık ara ürün olarak yetiştirilebilecek bir üründür (Çabuk, 1982). Nektar kaynağı olarak değerlendirilmesi çiçeklenme dönemini kapsamakta ve çiçeklenme sonuna doğru bu özelliğini yitirmektedir. Dolayısıyla bir miktar kalite kaybıyla birlikte çiçeklenme sonunda hasat edilmesi durumunda aynı alanın hem arı merası, hem de yem bitkisi olarak değerlendirilmesi mümkün olacaktır. Bu şekilde alan kullanım etkinliği de artacaktır. Yem bitkisi olarak kuru ot ve silaj amaçlı yetiştiriciliği yapılmaktadır (Tuncer, 2014). Bahsedilen amaçla değerlendirildiğinde hasadının \%50 çiçeklenme döneminde olması önerilmektedir (Sağlamtimur ve ark., 1989).

Anılan bitkinin aynı dönemde arı merası ve kaba yem üretimi amacıyla değerlendirilmesi açısından çiçeklenme ve verim üzerinde olumlu gelişmelerin sağlanması oldukça önemlidir (Tuncer, 2014).

Başbağ ve ark. (2001), Diyarbakır koşulları 1996-97 yılları arasında kışlık ara ürün olarak yetiştirilen arıotunda farklı tohum miktarlarının (1.0-1.5-2.0-2.5 $\mathrm{kg} \mathrm{da}^{-1}$ ) bitki boyu, yaş ot ve kuru ot miktarına olan etkilerini incelemişlerdir.
Araştırmada bitki boylarının 87-90 cm arasında olduğunu ve tohum miktarlarının bitki boyuna etkisinin önemsiz olduğunu, yaş ot verimlerinin 1638-2123 $\mathrm{kg} \mathrm{da}^{-1}$ arasında varyasyon gösterdiğini ve tohum miktarlarının yaş ot verimine etkisinin istatistiki olarak önemsiz bulunmasına rağmen tohum miktarlarının artması ile artış gösterdiğini, kuru ot verimlerinin ise 472-600 kg da-1 arasında belirlendiğini ve tohum miktarlarının artışına bağlı olarak arttığını bildirmektedirler.

Bilgen ve Özyiğit (2005), Çukurova koşullarında 1999-2001 yılları arasında yürüttükleri denemede, arıotunda vejetatif gelişmenin çiçeklenme özellikleri üzerine etkilerini incelemişlerdir. Yapılan analiz sonuçlarında en fazla etkileyen özelliğin kuru madde miktarı, en az etkileyen özelliğin ise bitki boyunda olduğunu vurgulamaktadırlar. Çiçekli kalma süresi, vejetatif özelliklerden etkilenmesine karşın, bu etkinin çiçek sayısına olan etkiye oranla daha düşük olduğu saptanmış ve çiçeklenme başlangıç tarihi vejetatif özelliklerden en az etkilenen çiçeklenme özelliği olduğunu bildirmişlerdir.

Tuncer (2014), Yozgat şartlarında 2013 yılı Mart Ayı'nda yaptığı çalışmada aynı sezonda nektar bitkisi ve yem bitkisi olarak değerlendirilecek bir arıotu tesisinin $7.5 \mathrm{~kg} \mathrm{da}^{-1}$ azot dozuyla gübrelenmesi ve $\% 50$ çiçeklenme döneminin sonunda hasat edilmesi en uygun işlem olduğunu bildirmiştir.

Karadağ ve Büyükburç (2001), Tokat-Kazova koşullarında kışlık olarak yetiştirilen arıotunun sıra aralığının ot ve tohum verimi üzerine etkilerinin incelendiği bir araştırmada, ortalama biyolojik verimin $361.9-485.2 \mathrm{~kg} \mathrm{da}^{-1}$ ve tohum veriminin 7.3-11.7 kg da ${ }^{-1}$ arasında değiştiği bildirilmişlerdir.

Çukurova koşullarında arıotu çeşitlerinin geliştirilmesi ve yeşil yem üretimi amacıyla yapılmış bir çalışmada, $1500 \mathrm{~g} / \mathrm{da}$ tohum kullanılarak en yüksek yeşil ot veriminin elde edildiği belirlenmiştir (Çabuk, 1982).

Bu araştırma ile, Şanlıurfa koşullarında sonbahar ekim periyodunda yetiştirilen arıotu bitkisi için, farklı miktarlarda uygulanan tohumluğun bazı morfolojik özellikler ile daha yüksek verim ve kalitede kaba yem üretme imkanlarının araştırılması hedeflenmiştir. 


\section{Materyal ve Metot}

Araştırma Şanlıurfa ili, Harran ovası ekolojik koşullarında tesadüf blokları deneme desenine göre 4 tekerrürlü olarak kurulmuş ve Ukrayna menşeli Ambra, sertifikalı arıotu tohumu materyal olarak kullanılmıştır.

Deneme yeri topraklarının ana materyali kolluviyal olup, kırmızımsı kahverengi derin toprak özelliğindedir. Yapılan analizler sonucunda deneme yeri topraklarının ağır bünyeli, tuzlulukları zararsız, hafif alkali reaksiyonda, kireçli, organik madde yönünden fakir, fosforca yetersiz, potasyumca zengin durumda olduğu belirtilmiştir (Dinç ve ark., 1988).

Çizelge 1. Şanlıurfa iline ait iklim verileri (Anonim: 2016-17)

Table 1. Some climate data of Şanlıurfa province (Anonymous, 2016-17)

\begin{tabular}{|c|c|c|c|c|}
\hline $\begin{array}{l}\text { Aylar } \\
\text { Months }\end{array}$ & $\begin{array}{l}\text { Ort.Sic. } \\
\left({ }^{0} \mathrm{C}\right) \\
\text { Mean tem. }\left({ }^{0} \mathrm{C}\right)\end{array}$ & $\begin{array}{c}\text { Ort. Gün. süresi } \\
\text { (Saat) } \\
\text { Mean sunshine duration (hour) }\end{array}$ & $\begin{array}{l}\text { Ort. Nispi } \\
\text { Nem (\%) } \\
\text { Mean relative humidity (\%) }\end{array}$ & $\begin{array}{l}\text { Yağış Miktarı }\left(\mathrm{kg} / \mathrm{m}^{2}\right) \\
\text { Precipitation }(\mathrm{mm})\end{array}$ \\
\hline $\begin{array}{l}\text { Kasım-2016 } \\
\text { November-2016 }\end{array}$ & 12.6 & 5.9 & 42.9 & 23.3 \\
\hline $\begin{array}{l}\text { Aralık-2016 } \\
\text { December-2016 }\end{array}$ & 5.4 & 2.5 & 70.1 & 101.1 \\
\hline $\begin{array}{l}\text { Ocak-2017 } \\
\text { January-2017 }\end{array}$ & 5.4 & 4.2 & 61.9 & 9.0 \\
\hline $\begin{array}{l}\text { Şubat-2017 } \\
\text { February-2017 }\end{array}$ & 7.7 & 7.4 & 45.3 & 1.8 \\
\hline $\begin{array}{l}\text { Mart-2017 } \\
\text { March-2017 }\end{array}$ & 12.7 & 6.3 & 57.1 & 55.2 \\
\hline $\begin{array}{l}\text { Nisan-2017 } \\
\text { April-2017 }\end{array}$ & 16.6 & 7.4 & 50.2 & 79.2 \\
\hline
\end{tabular}

Araştırmanın yürütüldüğü aylara ait Şanlıurfa ili iklim değerleri Çizelge 1.'de verilmiştir. 2016 ile 2017 vejetasyon döneminde en düşük ortalama sıcaklık $5.4{ }^{\circ} \mathrm{C}$ derece ile Aralık ve Ocak aylarında, en yüksek ortalama sıcaklık $16.6{ }^{\circ} \mathrm{C}$ ile Nisan Ayı'nda tespit edilmiştir. En düşük güneşlenme süresi (2.5 saat) Aralık, en yüksek güneşlenme süresi (7.4 saat) Şubat ve Nisan aylarında, en düşük nispi nem oranı (\%42.9) Kasım ayında, en yüksek nispi nem oranı (\%70.1) Aralık ayında; en düşük yağış miktarı $(1.8 \mathrm{~mm})$ Şubat ayında, en yüksek yağış miktarı (101.1 mm) Aralık ayında gerçekleşmiştir. 2016- 2017 ürün yetiştirme döneminde, Şanlıurfa'da toplam 269.6 mm yağış düşmüştür (Anonim, 2016-17).

Araştırmada; Kasım Ay'ının ikinci haftasında Eyyübiye kampüsü Tarla Bitkileri uygulama alanında $30 \mathrm{~cm}$ sıra arası mesafede elle ekilmiş ve 1.0, 1.5, 2.0 ve $2.5 \mathrm{~kg} \mathrm{da}^{-1}$ olmak üzere, dört farklı tohum miktarı ele alınmıştır. Parseller 5 metre uzunluğunda ve 4 sıradan oluşmuştur. Ekimde

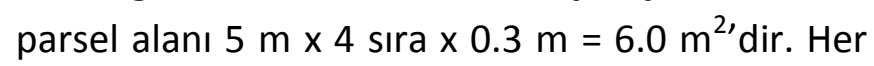
parselde kenar etkisini gidermek için parsel başlarından $50 \mathrm{~cm}$, blok kenarlarından birer sıra atılıp, hasat alanı $4 \mathrm{~m} \times 2$ sıra $\times 0.3 \mathrm{~m}=2.4 \mathrm{~m}^{2}$ olarak belirlenmiştir. Karakterlere ilişkin tüm ölçümler ve gözlemler belirlenen bu alanda yapılmıştır. Denemede, dekara saf $6.0 \mathrm{~kg} \mathrm{~N}$ ve 6.0 kg $\mathrm{P}_{2} \mathrm{O}_{5}$ olacak şekilde, 20.20.0 kompoze gübresi kullanılmıştır. Yetiştirme süresince; tarlada sulama, çapalama ve gerekli diğer bakım işlemleri yapılmış olup. Arıotu yaş yem olarak \%50 çiçeklenme döneminde hasat edilmiştir.

Denemede; bitki boyu $(\mathrm{cm})$, yaş ot ve kuru ot verimleri ( $\mathrm{kg} \mathrm{da}^{-1}$ ), yan dal sayısı (adet) ve ham protein oranı (\%) değerleri ortalamaları, Tesadüf Blokları Deneme Desenine göre varyans analizine tabi tutulmuş ve önemli çıkan ortalamalar, Tukey testine göre karşılaştırılmıştır.

\section{Araştırma Bulguları ve Tartışma}

Deneme yılında, Çizelge 2'den, bitki boyu değerlerinde 3 farklı grubun oluştuğu, en yüksek değerin $60.16 \mathrm{~cm}$ ile $1.0 \mathrm{~kg} \mathrm{da}^{-1}$ ve $59.36 \mathrm{~cm}$ ile $1.5 \mathrm{~kg} \mathrm{da}^{-1,}$ dan, en düşük değerin ise $48.46 \mathrm{~cm}$ ile $2.5 \mathrm{~kg} \mathrm{da}{ }^{-1,}$ daki tohum miktarından ölçüldüğü 
görülmektedir. Bunun sebebi; bitkiye düşen toprak alanın genişlemesi besin maddesi miktarının daha fazla olmasından dolayı bitki arası rekabetlerin azalarak boylarında kısalma olabileceğini bildiren Sağlamtimur ve ark. (1989), Uçar ve Tansı (1996) ve Kaymakkavak (2007) elde ettiğimiz bulgularımızı desteklemektedir.

Yan dal sayısı bakımından sıra arası mesafelerin önemli bulunmadığı istatistiki analiz sonuçlarına karşın rakamsal olarak en yüksek değerin (8.50 adet/bitki) $1.0 \mathrm{~kg} \mathrm{da}^{-1}$ tohumluktan, en düşük değerin de (6.75 adet/bitki) $2.5 \mathrm{~kg} \mathrm{da}^{-1}$ tohum miktarından elde edildiği Çizelge 2'den izlenmektedir. Denemede elde ettiğimiz bulgular literatür bulgularından daha yüksek bulunmuştur. Bu durum Şanlıurfa'daki ekolojik koşulların bölge koşullarına göre daha elverişli olması ve denemelerin yürütüldüğü lokasyonlardaki iklim ve toprak özelliklerinin farklılı̆ının yanı sıra, karakterin saptanmasında izlenen yoldan kaynaklanabileceği söylenebilir. Denemeden elde ettiğimiz bulgularımızı Bilgen ve Özyiğit (2005), Doyduk (2014)'un bulguları ile uyum içerisindedir.

Çizelge 2. Arıotu'nda farklı tohum miktarlarının bitki boyu, yan dal sayısı, kardeşlenme sayısı, yaş ve kuru ot verimleri, ham protein oranına ait ortalama değerler ve oluşan gruplar

Table 2. Plant different amounts of seeds in phacelia number of side branches, number of siblings, age and hay yield, average values of crude protein ratio and groups formed

\begin{tabular}{|c|c|c|c|c|c|}
\hline $\begin{array}{l}\text { Tohum Miktarı (kg } \\
\text { da }{ }^{-1} \text { ) } \\
\text { Amount of seed ( } \mathrm{kg} \\
\left.\qquad \mathrm{d}^{-1}\right)\end{array}$ & $\begin{array}{l}\text { Bit. Boyu }(\mathrm{cm}) \\
\text { Plant height } \\
(\mathrm{cm})\end{array}$ & $\begin{array}{c}\text { Yan Dal Say. } \\
\text { (adet/bitki) } \\
\text { Side branch } \\
\text { Number } \\
\text { (Piece/plant) }\end{array}$ & $\begin{array}{l}\text { Yaş Ot Ver. } \\
\quad\left(\mathrm{kg} \mathrm{da}^{-1}\right) \\
\text { Green herbage } \\
\text { yield }\left(\mathrm{kg} \mathrm{da}^{-1}\right)\end{array}$ & $\begin{array}{c}\text { Kuru Ot Ver. } \\
\left(\mathrm{kg} \mathrm{da}^{-1}\right) \\
\text { Dry herbage yield } \\
\left(\mathrm{kg} \mathrm{da}^{-1}\right)\end{array}$ & $\begin{array}{l}\text { Ham Prot. Oranı } \\
\text { (\%) } \\
\text { Crude protein } \\
\text { ratio (\%) }\end{array}$ \\
\hline $1.0 \mathrm{~kg}$ & $60.2 \mathrm{~A}$ & 8.5 & 2302.8 B & $403.4 \mathrm{~B}$ & $12.3 \mathrm{AB}$ \\
\hline $1.5 \mathrm{~kg}$ & $59.4 A$ & 8.3 & $3113.2 \mathrm{~A}$ & $508.7 A$ & $12.9 A$ \\
\hline $2.0 \mathrm{~kg}$ & $52.6 \mathrm{AB}$ & 8.3 & $2592.0 \mathrm{AB}$ & 437.3 AB & 11.5 B \\
\hline $2.5 \mathrm{~kg}$ & $48.5 \mathrm{~B}$ & 6.8 & 2191.5 B & $422.1 \mathrm{AB}$ & $12.3 \mathrm{AB}$ \\
\hline $\begin{array}{l}\text { Ortalama } \\
\text { Mean }\end{array}$ & 55.2 & 7.9 & 2549.9 & 443.01 & 12.3 \\
\hline Tukey (\%5) & 8.11 & Ö.D. & 647.40 & 90.79 & 0.99 \\
\hline
\end{tabular}

*: $\mathrm{p}<0.05$ farklı harfle gösterilen ortalamalar arasındaki farklılıklar önemlidir.

*: 0.05 significant probability level

Çizelge 2'den görüldüğü gibi, tohum miktarlarının yeşil ot verimi üzerine etkisi incelendiğinde; en yüksek yeşil ot veriminin $3113.2 \mathrm{~kg} \mathrm{da}^{-1}$ ile $1.5 \mathrm{~kg} \mathrm{da}^{-1,}$ da ekilen tohumdan, en düşük değerin $2191.5 \mathrm{~kg} \mathrm{da}^{-1}$ ile $2.5 \mathrm{~kg} \mathrm{da}^{-1}$ a ekilen tohum miktarında saptanmıştır. Denemede, tohum miktarı arttıkça yeşil ot değerlerinde azalma kaydedilmiştir. Elde edilen yeşit ot verimi değerleri Sağlamtimur ve ark. (1989), Tansı ve ark. (1996) ve Dağ (2013) ile benzerlik göstermektedir. Ayrıca tohum miktarının artması, bitki boyu karakterinin azalmasına, buna paralel olarak da yeşil ot verimlerinde düşüşe neden olabileceğini bildiren Kaymakkavak (2007) ile uyum içindedir.

Tohum miktarları bakımından en yüksek kuru ot veriminin $508.7 \mathrm{~kg} \mathrm{da}^{-1}$ ortalama değeri ile 1.5 $\mathrm{kg} \mathrm{da}{ }^{-1}$ ’ Iı tohum miktarından ekilen bitkilerde, en düşük ortalama değerin ise $403.4 \mathrm{~kg} \mathrm{da}^{-1}$ ile $1.0 \mathrm{~kg}$ $\mathrm{da}^{-1}$ da ki tohumluk miktarında ekilen bitkilerde ortaya çıktığı Çizelge 2'den izlenebilir. Anılan karakterin kuru toprakta hızlı büyüme ve çiçeklenme özelliği göstermesinin yanı sıra, değişik toprak ve iklim tiplerine adaptasyon kabiliyetine sahip olup, farklı verim değerleri verebileceğini bildirilmektedir (Wyland ve ark., 1996; Stivers-Young, 1998). Ayrıca, Başbağ ve ark. (2001), Diyarbakır'da kışlık ara ürün olarak yetiştirdikleri arıotunda farklı tohum miktarlarının etkilerinin araştırdıkları çalışmada, kuru ot verimlerinin 472-600 $\mathrm{kg} \mathrm{da}^{-1}$ arasında değiştiğini belirlemişlerdir.

Yem bitkilerinde ilk bakılan kalite kriterlerinden biri olan ham protein oranı değerlerinin belirtildiği Çizelge 2 incelendiğinde, tohum miktarlarının ham protein oranına etkilerinin önemli olduğu, en yüksek ham protein oranı değerinin \%12.9 ile 1.5 kg tohumluk miktarında ekilen bitkilerden elde 
edildiği, en düşük değerin ise \%11.5 ile $2.5 \mathrm{~kg}$ tohumluk miktarında ekilen bitkilerde ortaya çıktığı görülmektedir. Çıkan sonucun yeşil ot ve ham protein oranları değerleri ile ilgili olmasından dolayı beklenen bir sonuç olduğu söylenebilir. Bulgularım Kaymakkavak (2007) ile uyum içindedir.

\section{Sonuç ve Öneriler}

Elde edilen sonuçlara göre, Şanlıurfa ili iklim ve toprak koşullarında, kışlık ara ürün olarak, arıotu yetiştiriciliği yapılabileceği, kaliteli ve yüksek ot verimi için $1.5 \mathrm{~kg} \mathrm{da}^{-1}$ tohumluk kullanımının tercih edilmesi gerektiği söylenebilir.

\section{Kaynaklar}

Anonim, (2016-17). Şanlıurfa ili iklim verileri. Devlet Meteoroloji İşleri Genel Müdürlüğü. Ankara

Ateş, E., Coşkuntuna, L. \& Tekeli, A.S. (2010). Plant growth stage effects on the yield, feeding value and some morphological characters of the fiddleneck (Phacelia tanacetifolia Benth.). Cuban J. Agric. Sci. 44: 425 428.\&

Başbağ, M., Saruhan, V. \& Gül, ì. (2001). Diyarbakır koşullarında farklı tohumluk miktarlarının arıotu (Phacelia tanacetifolia Benth.) 'nda bazı tarımsal özellikler üzerine etkisi, GAP 2. Tarım Kongresi (s: 985-992). 24-26 Ekim, 2001, Şanlıurfa.

Bilgen, M., \& Özyiğit, Y. (2005). Arıotunda (Phacelia tanacetifolia Benth.) vejetatif gelişmenin çiçeklenme özellikleri üzerine etkisi. Akdeniz Üniversitesi Ziraat Fakültesi Dergisi, 18(2), 235-240.

Çabuk, A. (1982). Çukurova koşullarında fazelya (Phacelia tanacetifolia Bentham)'nın tohumluk miktarının verim ve tarımsal karakterlere etkisi üzerine bir araştırma. Ç.Ü.Z.F. Tarla Bitkileri Bölümü, Yüksek Lisans Tezi. Adana.

Dağ V. (2013). Farklı azot dozlarının arıotu (Phacelia tanacetifolia Bentham I'nda verim ve bazı tarımsal karakterlere etkisi. Yüzüncü Yıl Üniv. Fen Bil. Enst. Tarla Bit. Anabilim Dalı, Y. Lisans Tezi No:338027, Van.

Dinç, U., Özbek, H., Yeşilsoy, P., Çolak, A.K., \& Derici, R. (1988). Harran Ovası toprakları. Çukurova Üniversitesi Ziraat Fakültesi Toprak Bölümü, TÜBiTAK- TOAG 534 No'lu Proje, Adana.

Doyduk, I. (2014). Çukurova koşullarında farklı arıotu (Phacelia tanacetifolia Bentham) çeşitlerinde farklı ekim zamanlarının verim ve bazı tarımsal karakterler üzerine etkileri. Ç.Ü.Z.F. Tarla Bitkileri Anabilim Dalı Yüksek Lisans Tezi No:353653.

Genç Lermi, A. \& Palta, Ş. (2014). The effects of different sowing dates of fiddleneck (Phacelia tanacetifolia Bentham) during the autumn and spring sowing periods on the forage yield and quality. Bartın Orman Fakültesi Dergisi, 16 (23-24): 11-18.

Jepson, W. L. (1970). A manual of the flowering plants of California. Univ. of Clifornia Press. Berkeley and Los Angeles.

Karadağ, Y. \& Büyükburç, U., (2001). Arıotunda (Phacelia tanacetifolia Benth.) farklı sıra aralığının ot ve tohum verimlerine etkileri, Türkiye 4. Tarla Bitkileri Kongresi (s: 143-148.), 17-21 Eylül 2001, Tekirdağ.

Kaymakkavak, D. (2007). Değişik bitki yoğunluklarının arıotu (Phacelia tanacetifolia Bentham.)'nda verim ve diğer bazı özelliklere etkileri. Ege Üniversitesi Fen Bilimleri Enstitüsü Tarla Bitkileri Anabilim Dalı Yüksek Lisans Tezi. No:200646.

Munz, A.P. (1973). Agric California Flora. Universty of California Press. Berkely and Los Angeles

Sabancı, C.O., Baytekin, H., Balabanlı, C., \& Acar, Z. (2010). Yem bitkileri üretiminin artırılması olanakları. http://www.zmo.org.tr/resimler/ekler/ 7e77c835af3d2a8_ek.pdf. Erişim Tarihi: 08.05.2018.

Sağlamtimur, T., Tansı, V., \& Baytekin, H. (1989). Çukurova koşullarında kışlık ara ürün olarak yetiştirilen arıotu (Phacelia californica Chamm.)'nda biçim zamanını bitki boyu ve ot verimine etkisi üzerinde bir araştırma. Çukurova Üniversitesi Ziraat Fakültesi Dergisi, 4(1), 76-83.

Stivers-Young, L. (1998). Growth, nitrojen accumulation and weed suppression by fall cover crops following early harvest of vegetables, Hort Sci., 31 (1), 60-63.

Tansı, V., Kızılşimşek, M., Kumova, U., \& Sağlamtimur, T. (1996). Çukurova bölgesinde yeni bir yem bitkisi olan Phacelia tanecetifolia Bentham'ın balarıları için kullanılma olanaklarının araştırılması, Teknik Arıcılık Dergisi (52), 2-6.

Tuncer, K. (2014). Farklı azot dozlarının arıotunun (Phacelia tanacetifolia Bentham) bitkisel özellikleri ve ot kalitesi üzerine etkisi. Bozok Üniversitesi Fen Bilimleri Enstitüsü Tarla Bitkileri Anabilim Dalı, Y.Lisans Tezi, No:372733, Yozgat.

Uçar, H., \& Tansı, V. (1996). Çukurova koşullarında farklı ekim zamanı ve sıra aralığının arıotunun (Phacelia tanacetifolia Benth.) tane verimi ve arı mer'ası olarak kullanılması bakımından etkileri. Türkiye 3. ÇayırMer'a ve Yembitkileri Kongresi (s: 415-421), 17-19 Haziran, Erzurum.

Wyland, L.L., Jackson, L.E., Cheney, W.E., Klonsky, K., Koike, S.T., \& Kimple, B. (1996). Winter cover crops in a vegetable cropping system: Impacts of nitrate leaching, soil water, crop yield, pests and management costs, agric. EcoSyst. Environm., (59), 117. 